\title{
Mass timber in the circular economy: paradigm in practice?
}

Adrian Campbell BSC, MSt, MICE, CEng

Founder and Director, changebuilding, Farnham, UK

(ac@changebuilding.com) (Orcid:0000-0002-9384-0484)

\begin{abstract}
Mass timber products such as cross-laminated timber have increased in popularity in the past decades. Their relative novelty, however, means that there is little actual experience of what happens to the products at end of life. Despite promoting the use of natural capital, biotic materials are not often covered in discussions on construction in the circular economy. Equally, it is unclear what model is most appropriate for construction to incorporate circular thinking. Different actions for circularity are reviewed against sustainable construction ambitions, and a simple model with basic circular actions is proposed as a means to review mass timber construction. Suggestions for how to adapt mass timber systems to include circular methods are presented, including design for combined manufacture and assembly and disassembly, the identification of future markets, improving the durability of timber buildings and acknowledging the wider system value of forestry.
\end{abstract}

\section{Introduction}

Timber has been used in construction for millennia. Until the first Industrial Revolution in about 1750 , and what is sometimes called 'The Great Acceleration', biotic materials (wood, fibre, etc.) were society's primary resource. Rapid industrialisation led to the development of many familiar construction technologies using predominately extracted materials such as iron and aggregates. These materials have come to dominate both architectural and engineering designs.

However, in recent years, advances in gluing, fixing and manufacturing technologies have allowed a new generation of large mass timber products to be used in ever larger and increasingly complex building projects, first through gluelaminated timber beams, and now other beam types or large panel products such as cross-laminated timber (CLT). These products are promoted as part of an inherently sustainable and now potentially more circular use of natural resources.

Mass timber is one of the few structural products that have emerged that might challenge the current dominance of steel and reinforced-concrete design in the future. If adopted more broadly, its use may suggest that there is an opportunity to change methods of construction to ones that are inherently renewable while still delivering the expected building performance. Expanding the understanding on the methods of production may also identify system benefits beyond just the buildings themselves.

\subsection{Mass timber and its use}

Mass timber is used in this paper to denote the family of timber products made by connecting a series of smaller timber elements together to form larger panel or beam products. This includes products such as CLT, laminated veneer lumber and gluelaminated (glulam) beams. The connection is not only typically made with glue, but can also be through nails, dowels or interlocking. Alternative terms include solid laminate timber systems (Hairstans, 2017), timber solid construction (directly translated from the German, Holz Massiv Construction) or massiv holz. It should not be confused with lightweight timber frame construction that uses engineered wood products such as plywood or orientated strand board, or solid wood, a term used in the UK to mean sections of sawn timber (lumber) such as joists.

The UK construction industry's often-noted reluctance for innovation makes the speed of uptake of mass timber as a wholebuilding structural solution impressive. CLT has been used in residential buildings and schools for about 20 years and its use is being broadened into commercial offices, leisure and now industrial sectors. The advantages of faster programmes, waste reduction, off-site production, lightness and also current near cost neutrality (see 'UK 100 CLT', an unpublished 2018 book draft by Waugh Thistleton Architects) make it commercially, as well as environmentally, attractive. Its use aligns to many of the construction industry's own strategic ambitions for 2025 for carbon dioxide, cost and programme reduction (HMG, 2013), with specialist timber design and construction skills now also being exported to other countries. It appeals to architectural ideals of visual quality when exposed and can help to deliver thermal benefits through improved airtightness and its inherent insulating properties.

Products follow basic engineering principles and have an expanding supply chain, making it easy to design and specify in regular and relatively simple buildings.

It connects intuitively to a feeling that something that grows should have less environmental impact than something that does not; it is reasonably uncontested that products that come from established and certified forests mostly in Europe have inherently lower carbon dioxide or energy impacts, even with some degree of processing and transport (Dangel, 2017), and are renewable. 
Timber industry literature such as Lignatec (2015) emphasises the renewable benefit of using forests for products, showing a circular loop for either resources or carbon dioxide, including the use of waste wood for the drying. A broader systems loop with recycling is also sometimes noted (Dangel, 2017; Kaufman and Nerdinger, 2012). It is presented as an already optimised, efficient, sustainable and now circular system (Hairstans, 2017).

\subsection{Paper scope}

This paper therefore reviews some of the common statements about the benefits of the use of mass timber in building construction, and uses a simple model on adoption of the circular economy into the construction industry that reviews how well mass timber's use aligns to the ambitions of a circular economy.

It is intended to help identify current gaps in knowledge in order to stimulate further research and debate in the industry, broaden the debate on construction materials to include biotic materials that are often underrepresented in debates, and also suggest how circular economy methods may be implemented already by engineers in the absence of this more developed understanding.

While addressing resource flows, it is recognised that the model also needs to relate to necessary social and political challenges, or just the complexity of human nature, as identified as necessary for the adoption of the circular economy (Pomponi and Moncaster, 2017).

There are many interpretations of what constitutes a circular economy (Weetman, 2017). For simplicity, the British Standard (BSI, 2017: p. 10) for implementing the principles of the circular economy in organisations is used as the basis for the definition as an 'economy that is restorative and regenerative by design, and which aims to keep products, components and materials at their highest utility and value at all times, distinguishing between technical and biological cycles' (adopting the Ellen MacArthur Foundation's own definition (EMF, 2017a) in full).

\section{Construction in a circular economy}

Concepts within the circular economy are not new. Moreover, while there is significant information about how these concepts are brought together within a circular economy overall (EMF, 2017a, RSA, 2016; Weetman, 2017), there is less that relates directly to how the model fits to construction (the publications of Adams et al. (2017), Arup (2016), Cheshire (2016) and Hill (2015) are some notable exceptions).

When circular construction is described, Pomponi and Moncaster (2017) suggest that it is often at either a city (macro) or product (micro) level, with little relating to the building (meso) scale. This is typified by discussions on the use of particular alternative or waste materials such as coffee grounds, paper, glass bottles and so on as part of the output of everyday consumption (Hebel et al., 2014) or identifying the possibility for the increased 'flow' of materials through the specific designation of materials as either technical or biological nutrients. At the macro scale the role of the circular economy in addressing the increasing global urbanisation and scale of impacts of city systems (EMF, 2017b), or generally the built environment (Arup, 2016), is often noted.

As identified, there appears less debate about the building as an identifiable system. This includes how to influence changes to their delivery within a complex and already deeply networked system, and other issues such as the suitability of circular business models when applied to construction's inherently longer time periods; the possible benefit of building materials held as 'stocks' if retained for longer; the impact of changing building ownership over time - that is, the exchange value of products; or current ambitions and guidance on sustainable development and the differences, if any, on established engineering design aims.

These issues are discussed further to develop a clearer model for the adoption of the circular economy in construction and then the application of that to mass timber construction itself.

\subsection{Circularity and sustainability models}

There is a complex and overlapping array of issues associated with the circular economy that have each been used to varying degrees in construction including natural capitalism, cradle-tocradle $(\mathrm{C} 2 \mathrm{C})$ thinking, the performance or blue economies, and industrial symbiosis as examples (BSI, 2017; Weetman, 2017).

Established criteria for the adoption of sustainable development in construction can also be used to identify new features of a circular economy that move practice beyond these.

Table 1 identifies existing principles for the delivery of more sustainable structural design (IStructE, 2014) and compares this to others presented for a circular economy by both the Ellen MacArthur Foundation (EMF), using the ReSolve matrix, and the circular economy framework by Weetman.

This shows that there is significant overlap in the established environmental ambitions within sustainable construction and the principles of the circular economy - for example, long life, high recycled content, adaptability and flexibility, and also intent to use renewable materials.

What is perhaps more obvious within the circular economy principles than sustainable construction, however, is that these aspects rely on new and viable markets for a circular model to work. Remaking or sharing strategies are both not only opportunities for new business, but also challenging in breaking down embedded methods and attitudes. As noted by the Oxford academic and economist Kate Raworth (2017: p. 229), 'regenerative industrial design can only be fully realised if it is underpinned by regenerative economic design'. The imperative for the success of the circular economy in construction will be based on the ability to identify and enable these new markets, 
Table 1. Comparison of sustainable construction and circularity principles

\begin{tabular}{|c|c|c|c|c|c|c|c|c|}
\hline $\begin{array}{l}\text { Sustainable } \\
\text { construction } \\
\text { (IStructE) }\end{array}$ & & $\begin{array}{l}\text { ReSolve } \\
\text { (EMF) }\end{array}$ & $\begin{array}{l}\text { Circular economy } \\
\text { framework } \\
\text { (Weetman) }\end{array}$ & & $\begin{array}{l}\text { Possible circular } \\
\text { construction } \\
\text { system actions }\end{array}$ & & $\begin{array}{l}\text { Construction } \\
\text { industry } \\
\text { implications }\end{array}$ & $\begin{array}{l}\text { Timber industry } \\
\text { implications }\end{array}$ \\
\hline Long life & $\rightarrow$ & Optimise & Use it more & $\rightarrow$ & Hold & $\rightarrow$ & $\begin{array}{l}\text { Life-cycle costing and } \\
\text { valuing materials }\end{array}$ & $\begin{array}{l}\text { Ensuring durability in } \\
\text { use }\end{array}$ \\
\hline Adaptable/flexible & $\rightarrow$ & Share & Use it again & $\rightarrow$ & Hold & $\rightarrow$ & $\begin{array}{l}\text { Valuing materials in } \\
\text { use }\end{array}$ & $\begin{array}{l}\text { Adaptability and } \\
\text { integrity of } \\
\text { standard systems }\end{array}$ \\
\hline Low maintenance & $\rightarrow$ & Share & Use less & $\rightarrow$ & Modify less & $\rightarrow$ & $\begin{array}{l}\text { Durability and } \\
\text { maintenance }\end{array}$ & $\begin{array}{l}\text { Preservative use and } \\
\text { repair methods }\end{array}$ \\
\hline $\begin{array}{l}\text { Low carbon } \\
\text { dioxide }\end{array}$ & $\rightarrow$ & Exchange & Use less/renewables & $\rightarrow$ & Modify less & $\rightarrow$ & $\begin{array}{l}\text { Whole-building life- } \\
\text { cycle carbon dioxide }\end{array}$ & $\begin{array}{l}\text { Value of low and } \\
\text { sequestered carbon } \\
\text { dioxide }\end{array}$ \\
\hline Renewable & $\rightarrow$ & Regenerate & Renewable & $\rightarrow$ & Enhance & $\rightarrow$ & $\begin{array}{l}\text { Valuing renewable } \\
\text { materials and not } \\
\text { just energy }\end{array}$ & $\begin{array}{l}\text { Valuing forestry } \\
\text { carbon and } \\
\text { ecosystem services }\end{array}$ \\
\hline $\begin{array}{l}\text { High recycled } \\
\text { content }\end{array}$ & $\rightarrow$ & Loop & Remanufacture & $\rightarrow$ & Loop & $\rightarrow$ & $\begin{array}{l}\text { New markets beyond } \\
\text { industry }\end{array}$ & $\begin{array}{l}\text { New wood products } \\
\text { with post-consumer } \\
\text { content }\end{array}$ \\
\hline Locally sourced & $\rightarrow$ & Share & Safe and secure & $\rightarrow$ & Enhance/service & $\rightarrow$ & Local supply chains & $\begin{array}{l}\text { Forestry locations and } \\
\text { products in UK }\end{array}$ \\
\hline Recyclable & $\rightarrow$ & Loop & Waste $=$ food & $\rightarrow$ & Loop & $\rightarrow$ & $\begin{array}{l}\text { Design for } \\
\text { disassembly }\end{array}$ & $\begin{array}{l}\text { Disassembly methods } \\
\text { and post-consumer } \\
\text { timber use }\end{array}$ \\
\hline Low waste & $\rightarrow$ & Optimise & Use less & $\rightarrow$ & Modify less & $\rightarrow$ & Digital production & $\begin{array}{l}\text { Enhanced off-site } \\
\text { manufacturing } \\
\text { methods }\end{array}$ \\
\hline
\end{tabular}

exploring new opportunities inside as well as outside of the current industry networks.

The UN Sustainable Development Goals (2017) launched in 2016 are also becoming more influential in shaping the agenda for change. While these so-called global goals are intended to be used together, specific reference to materials is identified in goal 12 (sustainable consumption) and also noted in BS 8001 (BSI, 2017) as informing the overall context of the circular economy. If the circular economy broadens into a more inclusive campaign encompassing broader issues than resources - as is likely - it is possible that competing narratives could become problematic for communication and implementation of change within the industry. What are engineers striving for? Is it sustainable development or a circular economy? However, further discussion on this topic is beyond the scope of this particular paper.

\subsection{Circular construction principles}

As there are many different schools of thought that influence circular economy thinking, there will be many interpretations of what it constitutes. It will be important to establish a common reference for the construction industry.

Two key references are often quoted: $\mathrm{C} 2 \mathrm{C}$ thinking (McDonough and Braungart, 2003), focusing on the flow of nutrients in a system, and also the original work by Stahel (1982) on the selfreplenishing system, demonstrating the importance of longevity of use.
The 'butterfly' diagram (Figure 1) provides a simple representation of flows within a circular system, the separation between technical and biological nutrients (as also included in the definition of the circular economy itself) and the idealisation of loops to maintain material value.

Although this helps understand the general principles involved, it appears less easy to apply across the typical timescales and changing ownerships of products in construction or relate to the well-established subgroups within construction itself.

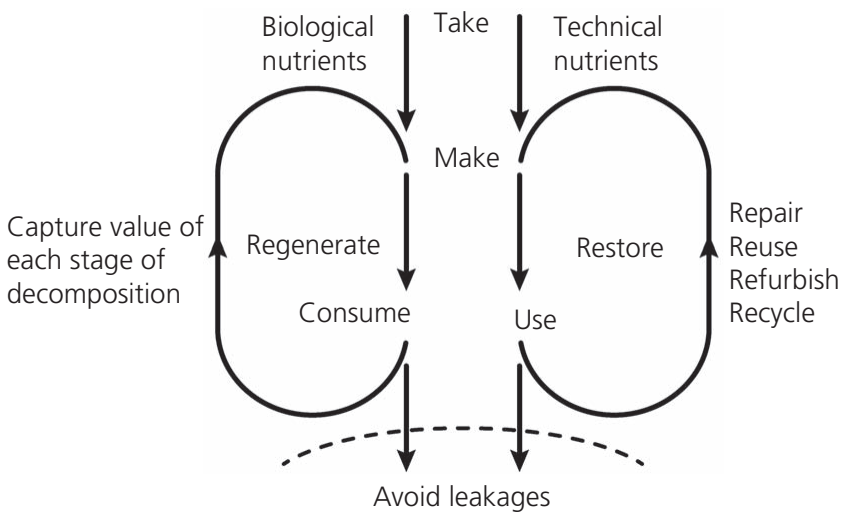

Figure 1. The 'butterfly' economy (adapted from Raworth, 2017) 
A clearer identification of the typical processes in construction such as the manufacturing, procurement, use, reuse and final disposal of a building and its components with time is needed.

Many processes (maintaining, refurbishing, remanufacturing and recycling) can also take place within a building's lifetime irrespective of the designation of a product being either a technical or biological nutrient. The nutrient designation is clarified in BS 8001:2017 (Section 2.18.2, Note 2) (BSI, 2017: p. 11), noting it is based on 'which of these [flows] it feeds back to, and not necessarily which one it originates from'. Biogenic materials used in construction could therefore theoretically 'switch' between cycles in their lifetime.

The process of restoring within this approach is identified against technical nutrients and flows and defined as only maintaining that is, not reducing - resource quality. Restoring, in that sense, does not relate to a process of improving the overall system that would be a major opportunity for biotic systems. These are simply regenerated, which again does not identify the need to enhance overall biodiversity.

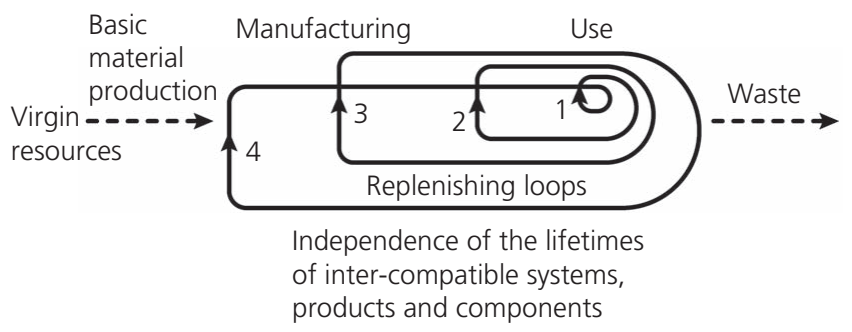

Figure 2. The self-replenishing system (after Stahel, 1982)
The second main reference is Stahel's original representation of a self-replenishing system. His diagram for product life extension, with replenishing loops that retain material value (Stahel, 1982), is shown in Figure 2.

This alternative approach, based more on longevity of use, presents opportunities to represent the longer time and varying ownerships within construction more clearly.

\subsection{A simple model for construction}

A modified version of Stahel's diagram as a simple model for circular construction is shown in Figure 3. This identifies familiar project processes (making, using and reusing), all well as the opportunity of also enhancing system value. This latter idea allows for the opportunity to increase, and not simply not just diminish, natural capital stocks.

The model identifies key system actions: losses through modification such as waste or energy release (modify less), time-related exchanges inherent in building use as extended loops representing the period of the use (hold) or change in ownership (loop), and alternates for the provision of services rather than product (service), within the typical stages of making, use and reuse. The opportunity to increase natural capital (enhance) is added.

Table 1 also includes these system actions and demonstrates that the basic concepts of circularity can align reasonably well with many established sustainability principles.

\section{Growing a circular economy}

The actions for circular construction are now applied to the use of mass timber construction.
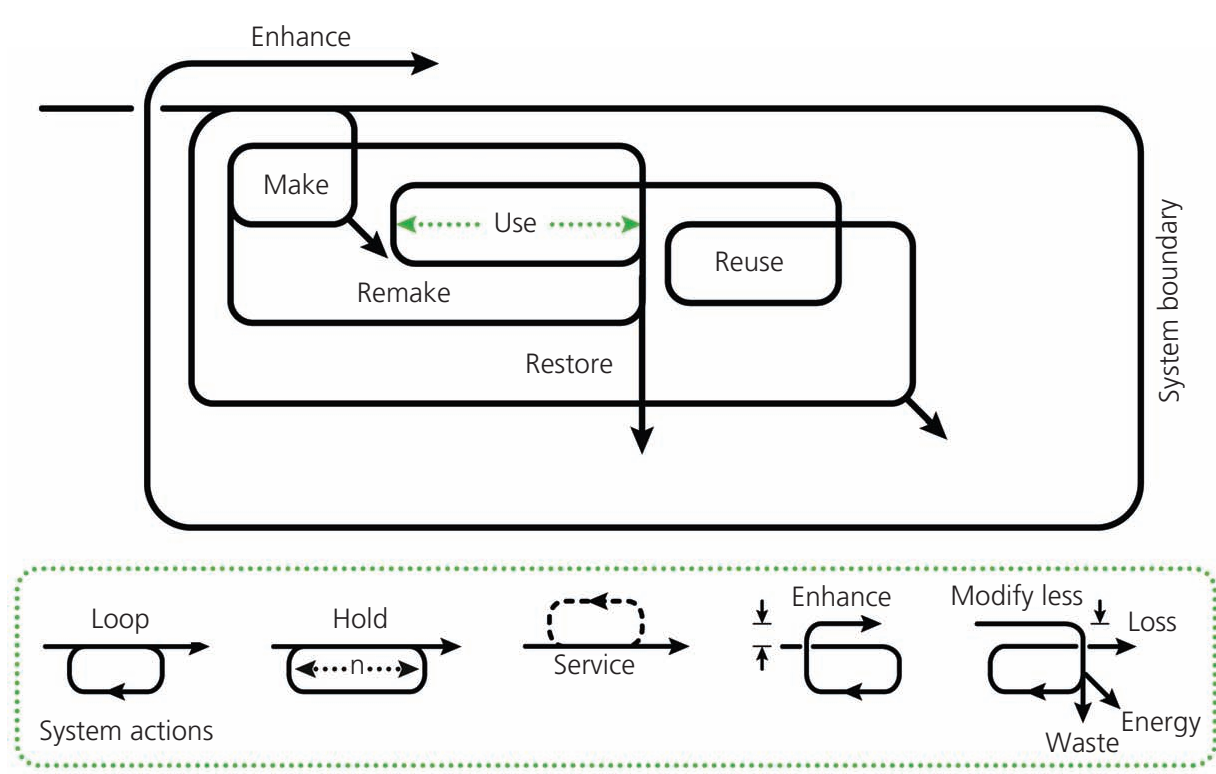

Figure 3. Model for circular construction 
A number of key aspects of the use of mass timber align with basic principles underpinning the circular economy: using current solar income (C2C), waste prevention (performance economy), wood co-products used as alternative products in manufacture (industrial ecology) and shift to biologically inspired materials (natural capital). These are all demonstrably positive aspects of the use of timber in construction.

This natural image, however, becomes more confused by the introduction of the methods to assemble timber into major sections (gluing, dowelling and nailing) or to modify it to improve its durability (preservative, flame spread, surface protection coatings or acetylation). While modifications provide better utility of the element, they alter the nature of the material and impact its future reuse or recyclability.

It is this difference between the natural image of wood and efficient industrialised production that forms the basis for many debates about the true environmental benefits for the use of mass timber systems. 'People love wood, but hate [sic] chainsaw' (Strykowski (2013), noted in the study by Hebel and Heisel (2017)) is a good summary of this attitude.

The following sections therefore discuss the proposed actions and identify areas for further research and debate and options for the development of engineering practice.

\subsection{Modify less}

This is an ambition to make buildings, avoiding adaption, improving production efficiency through digital or off-site manufacturing methods to avoid waste and finding ways to reduce the use of non-renewable resources and limit energy use losses.

\subsubsection{Product manufacturing}

The manufacturing of timber products is often identified as a circular process: growing trees form the sun's energy, managing forests to allow for sustainable yields, optimising the production of co-products and using any waste products as the energy input for drying or heating factories. Wood in this system is probably used at its highest possible market value, with co-products such as panels and bedding materials only made from lower-grade wood.

Over the last 50 years in the USA, efficiencies have improved with the use of digital methods. For instance, the utilisation of harvested wood has risen significantly with little or no waste incinerated or landfilled, and $88 \%$ of materials are being used for lumber or used as a raw material for other products (Dangel, 2017). Product manufacturing is optimised around new products for sale in an efficient closed subsystem loop.

Even if coming from a renewable source with closed-loop production, this method is similar to other linear (take, make, use and dispose) models of use. An extended closed-loop system might include post-consumer waste as an alternate resource for new timber products. Engineered panel products already include wood or wood fibre waste (TRADA, 2012), but there is a need to understand how much new modification is undertaken to make these products. A more open loop system would identify how material use could be extended into new alternative use markets.

The current commercial focus potentially also means that alternate, lower-value, non-product uses, such as biomass or pulp, could be prioritised if those either provide greater immediate financial returns or represent lower risk. In the EU, fuelwood currently accounts for about $22 \%$ of all roundwood production (Eurostat, 2017a). With significant pressure to hit renewable targets and with a constrained supply, the use of timber as woody biomass will compete with the use as a new product and determine future markets.

\subsubsection{Designing out adaption}

It is often necessary to alter wood products to overcome its inherent vulnerability to moisture, fire or pests. More considered design and detailing can sometimes help avoid these processes.

Untreated CLT does not meet higher surface spread of flame (SSF) class requirements and is often treated to meet regulated requirements when panels are used visibly. These treatments are often applied on-site and require regular maintenance. Once applied, this may change the designation of the wood for end-oflife recycling from grade B (industrial feedstock), to grade C (fuel grade), with consequential higher processing requirements as defined in PAS 111 (BSI, 2012).

On Sky's Health \& Fitness Centre project (Figure 4), the fire engineering design by Arup was used to nearly eliminate the need for SSF coatings, saving both initial cost and time on-site, minimising maintenance and also enhancing the end-of-life potential of CLT. This, however, did require more detailed consideration of the fire strategy and some other coating product to protect the timber surface in use.

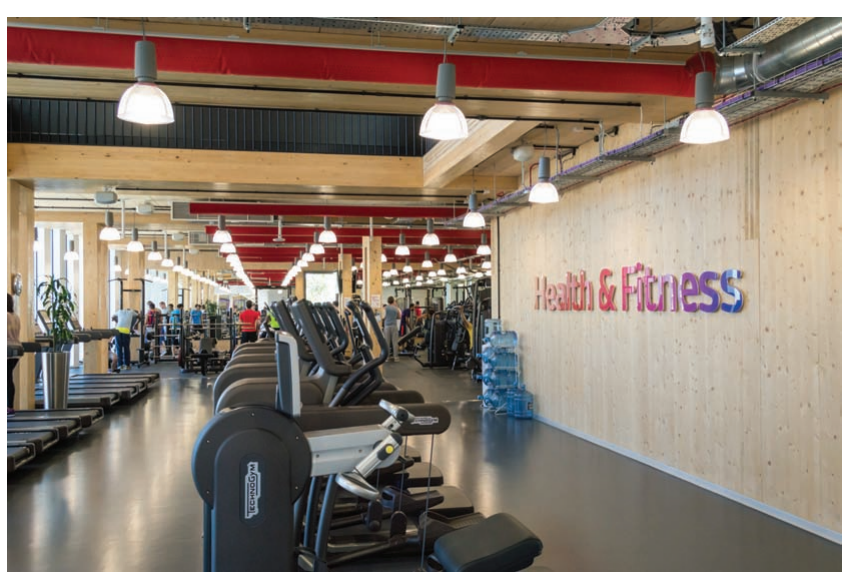

Figure 4. Sky Health \& Fitness Centre. (C) Arup 
New or more developed timber products may offer some solutions to modifying elements less, particularly avoiding glues. These include products such dowel-laminated products such as Brettstapel, interlocking CLT (Hairstans, 2017), or friction-fixed glulam (Dangel, 2017). Less processed mass timber systems are therefore available or being developed (Figures 5 and 6 ).

\subsection{Hold}

Some buildings become cherished and adapted successfully over time (Brand, 2015). Apart from good design for architectural quality and adaptability, longevity is also ensured through improved durability. This process leads to both reductions in the need for new materials and the establishment of new stocks of materials over time.

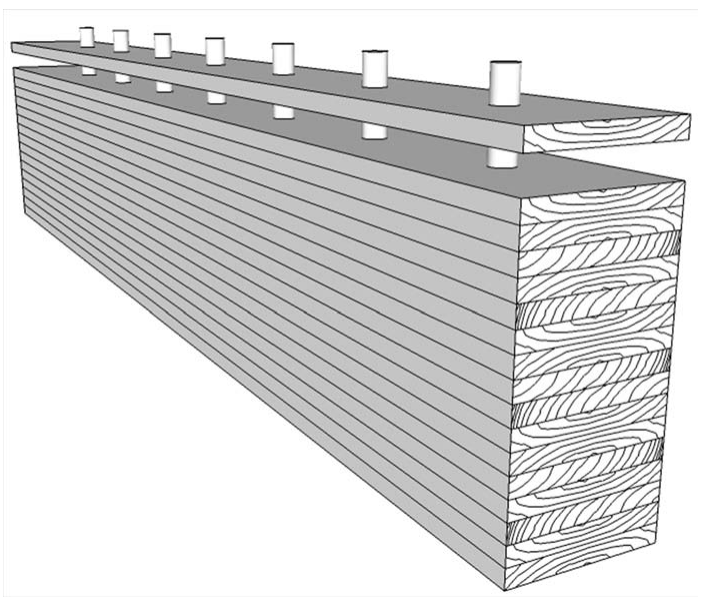

Figure 5. Brettstapel. () Centre for Offsite Construction and Innovative Structures (Cocis)

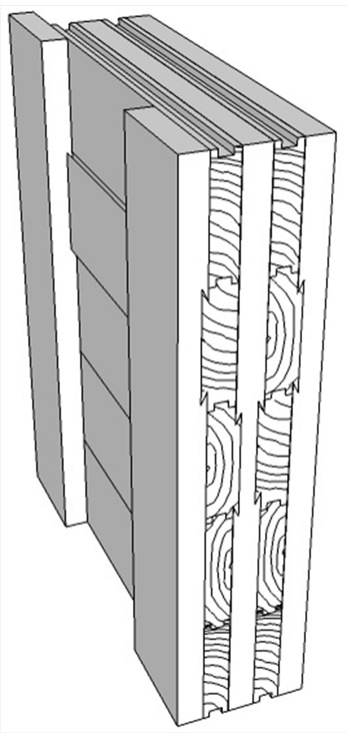

Figure 6. Interlocking CLT. (c) Cocis
The minimum period for holding timber in place to ensure the renewability of supply has been suggested to match timber rotation periods (Ramage, 2017) and therefore a minimum of 30 years, but potentially longer when slower-growth wood is used. The lower bound period is well within the normal 50-year design life for buildings (BSI, 2005), but still requires careful thought as to the methods of ensuring the suitable performance of components over this period. Products used from slower-growth forests or earlier demolition for commercial reasons would impact the basic assumption of renewability. The sensitivity of this is worthy of further study.

\subsubsection{Durability of wood products}

Wood products are susceptible to rot and pesticides, particularly when the moisture content of the wood is elevated over $20 \%$. Methods of detailing buildings, selecting species for the inherent durability or simply accepting the changes in appearance of wood with time were traditionally adopted (Dangel, 2017). These approaches are still valid, but often not adopted if timber systems are simply used as a substitute for other framing materials with little thought given to detailing for the use of timber from the beginning.

Typical design approaches for mass timber select suitable products types for the building and then verify the size and specification to meet the required performance criteria. This would include the exposure condition. Softwood products such as CLT are only suitable and importantly only certified through the product European Technical Approvals (ETA) for internal or protected spaces (defined as service class 1 or 2 (BSI, 2004)). As a general strategy, mass timber is kept within the thermal and waterproofing envelope to ensure that it is kept dry and avoids the need, in most cases, for preservatives.

From experience, durability remains one of the key issues identified by both developers and insurers as requiring more clarification. This could be addressed by clearer and accepted facade and roof waterproofing detailing, a focus on possible risks from internal water damage (such as bathrooms) and demonstration of simple methods for repair of timber systems if they do sustain damage.

\subsubsection{Carbon dioxide in buildings and the benefit of stocks}

Whole-building carbon dioxide assessments show that embodied impacts are significant at somewhere between 30 and $50 \%$ of lifetime emissions (UKGBC, 2017). Mass timber structures are identified as having the dual benefit of both reducing embodied emissions and also locking up carbon dioxide during their use until end of life. Data and methods need to be consistent and accurate for both these benefits to be assessed.

The measurement of embodied impacts has developed significantly in recent years with improved methodologies and clearer data. The Royal Institution of Chartered Surveyors (RICS) 
has recently adopted a new professional statement (RICS, 2018) that sets out one such standard methodology as the means for assessment in buildings. Other authors have noted the benefit during the operational life and not the full impacts including deconstruction, reuse or energy release (see ' $U K 100 C L T$ ', an unpublished 2018 book draft by Waugh Thistleton Architects). Past carbon dioxide scoping strategies have focused on cradle-togate or perhaps cradle-to-site values (compatible to the scope fully within the control of a new-build process), but as noted by John and Buchannan (2016), it is somewhat misleading to state timber embodied carbon dioxide values without the full life-cycle impacts.

Industry data published by Wood4Good (PE International, 2013) reflect this by giving options of impacts for various possible scenarios from full reuse, full energy release and also full landfill based on the building life-cycle boundaries of BS EN 15978:2011 (BSI, 2011). Previous research work by Arup (2014) also estimated current average scenarios for glulam manufacture to end of life. This suggested that approximately $50 \%$ of timber would be landfilled; $36 \%$, recycled into product, bedding or mulch; and the remaining $14 \%$, used as woody biomass. This generated an average full-life impact of glulam of about 0.60 kilograms carbon dioxide equivalent per kilogram $\left(\mathrm{kgCO}_{2} \mathrm{e} / \mathrm{kg}\right)$, or $-0.09 \mathrm{kgCO}_{2} \mathrm{e} / \mathrm{kg}$ if the benefits of impacts beyond end of life (stage D in BS EN 15978:2011) were included. This basis for the extended full-life impact assessment of mass timber therefore needs to be established for clearer carbon dioxide evaluations based on realistic future disposal scenarios.

Wood use also provides a sequestration benefit as building materials (or forests they come from) act as carbon dioxide stores. This is a separate benefit to carbon dioxide mitigation and can be reviewed for significance at both building and national levels and the potential benefit of holding stocks of carbon dioxide in buildings.

When assembled into a building, materials are held in place (as a stock) for the period of valuable use. Cheshire (2016) notes this building value to be a complex interaction of many factors including market forces, regulations and physical condition. The inherent value of the resources within the building (as materials banks) is not currently noted as a commercial factor in these decisions. There are few direct financial incentives to reduce material impacts other than credits from environmental assessment or taxes on some bulk materials. The update for Breeam in 2018 includes embodied carbon dioxide measurement in the Mat1 credit. This will still be for the current input qualities of materials, including some recycled content benefit, and not the potential future benefits of extended reuse.

Carbon dioxide sequestration has also been used previously as a means to justify offsetting other carbon dioxide reduction measures such as renewable energy generation, as on the Stadhaus project (Waugh et al., 2009). As criteria for better energy performance and renewable energy are clearly established in both building regulations and the UK government commitments to energy efficiency, the use of timber construction to reduce these requirements will be politically sensitive. It might therefore not be applicable as an alternative to renewable energy generation but as part of a widening of carbon dioxide scopes to include whole-building impacts or possibly a redefinition of zerocarbon dioxide ambitions to suit a broader understanding of actual building impacts.

The significance of sequestered carbon dioxide ('sequestered carbon') in mass timber products and forestry can also be estimated. The amount of carbon dioxide stored would obviously increase as more mass timber buildings are made from its current low base (SCI, 2017). An order of magnitude calculation based on data for current EU production demonstrates that carbon dioxide sequestered in mass timber products is currently less than about $0.05 \%$ of $\mathrm{EU}$ annual emissions. The total EU production of CLT in 2017 can be approximated as approaching 0.7 million $\mathrm{m}^{3}$ and glulam at about 1.7 million $\mathrm{m}^{3}$ (Ebner, 2017) out of a total roundwood production volume in the EU of 103 million $\mathrm{m}^{3}$ (Eurostat, 2017b). Using a rate of about 1 tonne carbon dioxide equivalent/tonne $\left(\mathrm{tCO}_{2} \mathrm{e} / \mathrm{t}\right)$ for sequestered carbon, this equates to roughly 1.2 million tonnes carbon dioxide equivalent/annum $\left(\mathrm{MtCO}_{2} \mathrm{e} / \mathrm{annum}\right)$ held in stock. This compares with the EU28 plus Iceland's annual emissions (EEA, 2017) of $4317 \mathrm{MtCO}_{2} \mathrm{e} / \mathrm{a}$ - that is, about $0 \cdot 03 \%$.

The broader carbon dioxide system relevance of forestry to national emissions is, however, very significant. EU27 forests contain $9977 \mathrm{Mt}$ of carbon dioxide (above and below ground biomass) and this increases by $1.5 \%$ each year (UNECE, 2015). With a suitable carbon-to-carbon dioxide factor (3.67), this equates to $36600 \mathrm{Mt}$ carbon dioxide, or nearly nine times the current EU28 annual emissions. This is one possible driver for the current investment - if small - in new UK forests and a broader appreciation of the important role of managed and historic woodlands in national carbon dioxide budgets. This is discussed further in Section 3.4.

Therefore, while embodied carbon dioxide is significant at a building level, the significance of product sequestration to regional emissions is very small at the current rates of production. Even with changing carbon dioxide reporting methods to include land use, land use change and forestry in national targets, and manufactured wood products within in EU 2030 climate and energy framework (Eurostat, 2017b), it is difficult to see how the scale of mass timber impacts on stores would change significantly in the near future.

Engineers could benefit from understanding and exploring this broader system-level benefit of productive woodlands to climate resilience and contributions to national carbon dioxide targets. They might possibly worry less about product-to-product comparisons even if they demonstrate benefits at a component or 
building scale. Put another way: engineers need to see the forests for the trees.

\subsection{Loop}

Circular flows of materials are one of the essential elements of the circular economy, maintaining product value at the highest possible level at all times. Although there are studies into the endof-life process for timber frames (CIB, 2014), there is little that applies to mass timber. Glulam beams were developed nearly 100 years ago, but other mass timber products are relatively new, with few precedents of reuse or disposal from buildings that have reached the end of life. The initial research and development of CLT has really happened only in the last 20 years (Brandner, 2013), for instance.

Irrespective of this lack of precedent, it is possible to identify processes that could lead to greater flows of materials.

\subsubsection{Design for manufacture, assembly and disassembly} Work by the architectural firm dRMM provides some examples of approaches to design for reuse and the potential challenges these place on conventional timber design practices.

The Naked House (Figure 7) was a fully demountable house that was installed and then dismantled to be reassembled on other sites. The CLT structure was taken apart by simply unscrewing elements. The Endless Stair sculpture (Figure 8), made of tulipwood hardwood CLT, was conceived with an ambition to be "endlessly reconfigurable' and was first installed outside Tate Modern for the London Design Festival in 2013. It was then reused in an altered format for two other shows in Munich and Milan in 2014.

For the Endless Stair, stair flights were left mostly intact with the landings designed to act as connectors to these larger pieces with bolted connections. Altering the interface with the flights allowed different geometries to be defined. Where flights had to be

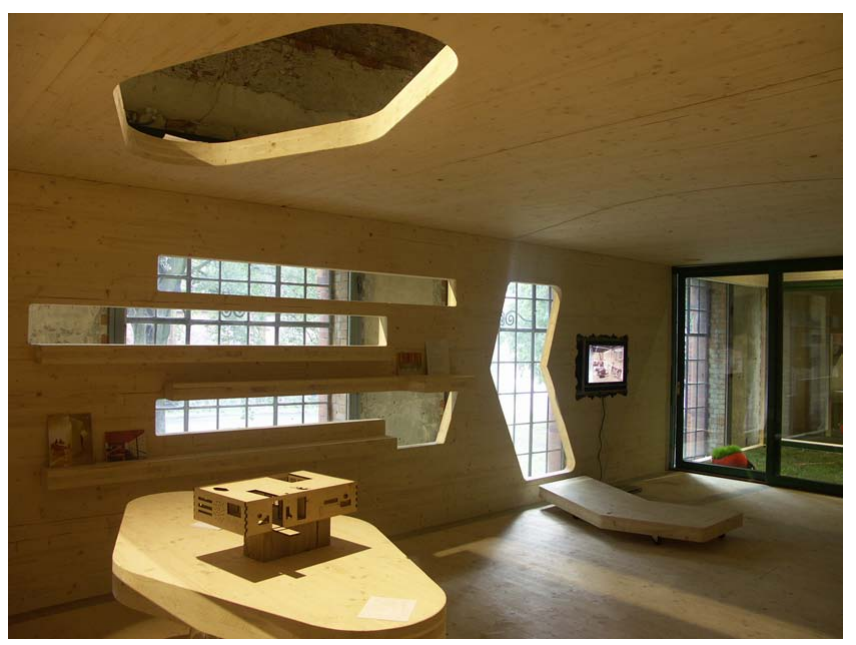

Figure 7. Naked House. (C) dRMM Architects

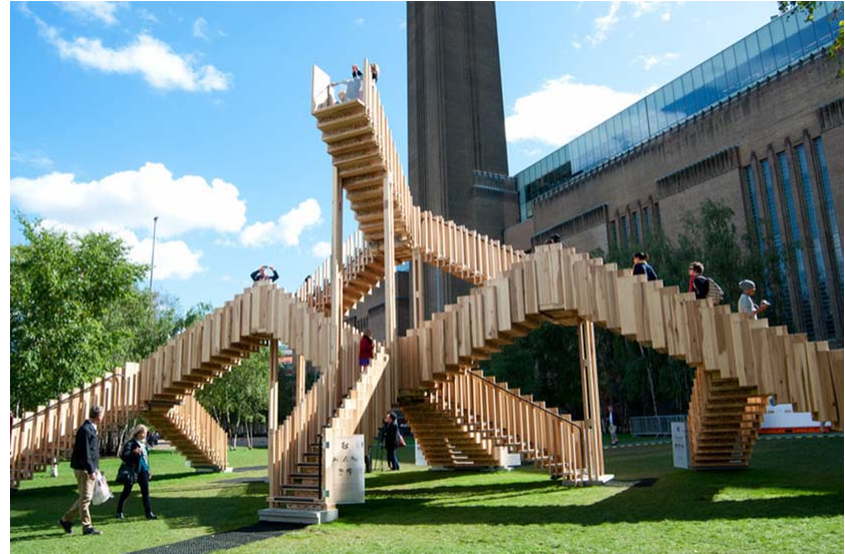

Figure 8. Endless Stair. ( $\odot$ Arup

adapted to suit new configurations or fixings had become firmly embedded, however, glued and/or screwed joints needed to be broken apart.

These examples identify both clear opportunities and challenges to effective disassembly at a larger scale. While current connectors and jointing methods make it very quick and efficient to fabricate and erect, it can be more problematic and time consuming to take them apart in the same way. Although there is significant innovation in the development of fixings technologies, disassembly potential is not currently a primary concern in product development.

Solutions to this may lie in defining standard zones for fixings such as lap joints in CLT or bearing details as a basis for cutting out of large panel or beam elements from building in the future without hitting connectors. New all-timber fixings systems are also being developed by manufactures, such as Hasslacher's (2018) X-fix systems that could make cutting apart very simple. Both offer simple deconstruction options that could be defined and potentially standardised if removing fixings is problematic.

Significant focus has been placed in recent years on the need for more efficient construction processes inherent in the adoption of much of the industry narrative around modern methods of construction (NHBC, 2016) or, recently, design for manufacture and assembly (DfMA) (Farmer, 2016). While there is also discussion on design for disassembly, these two aspects are rarely brought together. Changing the industry ambition to one of both making and 'unmaking' to form an overall goal for off-site that is, design for manufacture, assembly and disassembly $(\mathrm{DfMA}+\mathrm{D})$ - would inherently make the full life cycle part of the initial design ambition.

\subsubsection{Certification for circularity}

There are already certification methods aimed at demonstrating the long-term preservation of technical and biological nutrients through the $\mathrm{C} 2 \mathrm{C}$ certification scheme and product standards 
(Cradle to Cradle Products Innovation Institute, 2016). It is notable that few timber products have achieved this certification.

An informal review by the Alliance for Sustainable Building Products (private correspondence with the author in October 2017) of the $\mathrm{C} 2 \mathrm{C}$ banned list (C2C, 2017) suggests mass timber products do not include any of these substances. As glues (typically about $2 \%$ of the material volume) are the only main alteration of mass timber from its natural state before other treatments, adopting the certification might provide further confidence about the end of life as well as initial toxicity. New glues or other ways of jointing products such as friction welding of lamella (Dangel, 2017), or dowel fixing or interlocking (as noted earlier) might also be developed or deployed more commercially.

The circular qualities of mass timber products could be demonstrated through the broader use of the $\mathrm{C} 2 \mathrm{C}$ certification process, clarifying both initial and end-of-life qualities and possibly how biological materials can interchange with technical flows such as reuse and so on (noted as 'cycle switching' earlier) and still be fully consistent with circular processes. It could equally be linked to demonstrating the right environmental designation for waste products as PAS 111 (BSI, 2012) and allow higher-value uses from products at end of life, even if that is just easier energy recovery.

\subsubsection{Biomass versus product value}

The success of the circular economy rests heavily on viable new timber markets for materials. The wholesale product value of mass timber is about $€ 500 / \mathrm{t}$ (CBI, 2017) and its current biomass value at end of life of about $€ 50 / \mathrm{t}$ (Brack, 2017). The new market opportunity lies in this factor of 10 difference in value.

Lower-quality wood products already find their way into co-products (panels, bedding materials etc), and similar future markets are possible for mass timber. These divert products away from energy release but still represent a significant reduction of material value. Greater reuse or remaking therefore needs to be encouraged and that may require a broader engagement outside of the typical networks of the construction industry to other product manufacturers, makers or so-called prosumers (producer-consumers) enabled and encouraged to remake products using available digital tools. These new markets can be strengthened through greater standardisation and enabled through digital methods to provide knowledge of resources (Weetman, 2017).

CIB (2014) has noted that there is no significant research into the end of life of timber, and if reuse in building is to be encouraged, then investigation into these options should be carried out. It is possible to identify options. For instance, smaller CLT panels may be used in volumetric housing systems where visual quality may not be required.

These markets will, however, need to be substantial to develop a meaningful after-market price for mass timber that offsets the potential costs of disassembly and therefore avoid material quickly moving to use as biomass.

\subsubsection{Reuse specification}

The tendency of much engineering design is towards using new products. This improves predictability in design, reduces risks and avoids other time-related cost in longer design periods. To make reuse more common, engineers will need to accept reused timber as a standard product. This is a similar transition to the original reluctance to incorporate recycled or secondary products in concrete and to enable its incorporation through specification (Marsh, 2007) and methods to encourage the reuse of steel (Allwood and Cullen, 2012).

The National Structural Timber Specification (TRADA, 2017) already suggests reuse at the end of life in clause 5.1.4. It also promotes new materials 'free of damaged or defective parts' in clause 6.4. Engineers are therefore already at liberty to enable the reuse of materials through the specification. Wording of the specifications could be adapted to encourage more reuse, methods for regrading defined or alternative methods for applying higher factors of safety for materials used where necessary to improve confidence in products if information retained from the original product ETA is deemed insufficient. There are also simple opportunities to increase the use of radio-frequency identification tagging of elements or other smart methods to help retain knowledge of the product information and increase the ease of reuse in the future (Iacovidou et al. 2018).

\subsection{Enhance}

The circular economy encourages the use of regenerative and natural materials. However, rather than using the term 'restoring' in the broader sense of improving the quality of natural capital overall, it uses it in a specific sense of returning products or components back into the system within the technical nutrients cycle (BSI, 2017). It uses 'regenerative' as meaning replacing biological nutrients that may be consumed. The stated definition of the circular economy as 'restorative and regenerative' is therefore quite specific.

The term used in this paper notes 'enhancing' resources, whether that is measured in terms of carbon dioxide pools, biodiversity or ecosystem services, to differentiate it from this particular definition. The original expectations of eco-effectiveness, of doing good and not just less bad, as expressed in $\mathrm{C} 2 \mathrm{C}$ thinking (McDonough and Braungart, 2003), are worth further clarification in relation to timber use and forestry. Equally, the benefits of changing engineering approaches from basic product selection to more integrated systems could also potentially be emphasised.

The UK's Clean Growth Strategy (BEIS, 2017) supports the strategy to increase the benefit of and value of natural resources and plant 11 million new trees in the UK. While no specific date is provided for this, the UK government commitments to the 2015 Paris Accord to limit global temperature increases below $2^{\circ} \mathrm{C}$ and 
emphasis by the Committee on Climate Change (CCC, 2017) on the requirement to close current gaps in policies to meet legislated carbon dioxide budgets may provide some stimulus to deliver this.

The value of these new forests to counter climate-resilience challenges such as flooding, as well as providing ecosystem services to communities, presents an opportunity for engineers to adopt a broader view of the value of forestry beyond the immediate opportunity of renewable product manufacture.

The scale of planting suggested should however also be seen in the perspective of current policy. As a reference on scale, the new High Speed 2 project is intended to plant 7 million new trees over about 650 ha to blend the line into the landscape (HS2, 2016). This additional area would represent about $0 \cdot 2 \%$ of the current $3 \cdot 17$ million ha of woodlands (Forestry Commission, 2018), which equates to about $13 \%$ of all land area. This is significantly short of the suggested rates of about 15000 ha/year noted by the CCC to meet land use targets within the carbon dioxide budgets.

\subsection{Service}

Providing the same performance through an ongoing service rather than product is already used for some elements within buildings such as floor coverings and lighting services (Cheshire, 2016). Its broader adoption into building structures may be more complicated.

It may also be possible to reduce the need for buildings by new ways of working or more efficient production, but when related to building, a service delivery alternative is still more likely to be from finishes or furnishing components within the building than the main structure.

This was evident from experimental projects such as Arup's Circular Building (Schofield, 2016b) where building components were predominately manufactured to be returned or reused, and service options used for furniture, carpets and energy storage. The service periods for these elements are much shorter than the overall building design life (50 years) and it is therefore easier to identify a successful business model for them.

This is an area for further discussion about the application in construction generally, not only within the timber industry.

\section{Conclusions}

The benefits of large system changes take time to develop. As Meadows (2008: p. 23) notes, 'stocks take time to change, because flows take time to flow'. For construction, transitioning to a circular economy will take time, not least to change the established behaviours of a deeply networked industry.

There is significant overlap between ambitions of the circular economy and established ambitions for sustainable construction. The significant difference is whether the circular economy can help shape new markets and overcome some of the barriers that made these same sustainable construction ambitions hard to achieve.
Models for the application of the circular economy in construction will need to accommodate the established networked system, its processes and the time scales inherent in building. A simple model based on Stahel's work has been suggested to identify more clearly these processes and then to be used as basis to review mass timber construction and current incorporation of circular thinking. This suggests many positive aspects including production efficiency and forest carbon dioxide storage. However, the broader ambition for end-of-life reuse or remanufacturing is not as evident, and methods will need to be developed that help provide either more closed or open loop methods for reuse.

A common goal for design of making and then unmaking buildings (DfMA $+\mathrm{D})$ might be adopted to consider reuse as an essential part of design itself and be consistent with the idea of 'flows'. Equally important is the need to focus clearly on design and detailing of mass timber buildings for greater durability and holding 'stocks' of materials in place.

Mass timber systems already align with many of the policy ambitions for the industry such as skills improvement, faster construction and carbon dioxide reduction. The wider adoption of mass timber is therefore valuable in its own right as a marketready option.

Improvements at both industry systemic and engineering practice levels have been suggested to understand the full life of the product, including the better understanding of likely end-of-life scenarios for mass timber and a broader understanding of the value of forests.

Wood may well be a useful biomass energy source, but it is far too valuable a resource for construction to simply burn in the first, or even second, instance.

\section{Acknowledgements}

Ideas on timber and circularity were first presented and discussed at the IABSE Henderson Colloquium at Christ's College, Cambridge, in 2017. The discussions at that event have been very helpful in shaping early ideas. The author would also like to thank the grateful support of many other industry colleagues who have shared their views, commented on early drafts of the paper and helped make connections to other parts of the industry.

\section{REFERENCES}

Adams KT, Osmani M, Thorpe T and Thornback T (2017) Circular economy in construction: current awareness, challenges and enablers. Proceedings of the Institution of Civil Engineers - Waste and Resource Management 170(1): 15-24, https://doi.org/10.1680/jwarm.16.00011. Allwood J and Cullen J (2012) Sustainable Materials with Both Eyes Open. UIT Cambridge, Cambridge, UK. See http://www. withbotheyesopen.com/index.html (accessed 25/04/2018). Arup (2014) Embodied Carbon in Buildings and Timber. Arup, London, UK. Arup (2016) The Circular Economy in the Built Environment. Arup, London, UK. See https://www.arup.com/publications/research/section/ circular-economy-in-the-built-environment (accessed 05/11/2017). 
Engineering Sustainability

Volume 172 Issue ES3
Mass timber in the circular economy:

paradigm in practice?

Campbell
BEIS (Department for Business, Energy and Industrial Strategy) (2017) UK Clean Growth Strategy. BEIS, London, UK. See https://www.gov.uk/ government/publications/clean-growth-strategy/clean-growth-strategyexecutive-summary (accessed 17/03/2018).

Brack D (2017) The Impacts of the Demand for Woody Biomass for Power and Heat on Climate and Forests. Chatham House, London, UK. See https://www.chathamhouse.org/publication/impacts-demandwoody-biomass-power-and-heat-climate-and-forests (accessed 17/10/ 2017).

Brand S (2015) How Buildings Learn: What Happens After They Are Built. Penguin, London, UK.

Brandner R (2013) Production and Technology of Cross Laminated Timber (CLT): a State of the Art Report, in COST Action FP1004 with TU Graz. University of Bath, Bath, UK.

BSI (2004) BS EN 1995-1-1:2004 + A1:2008: Design of timber structures: part 1-1: general - common rules and rules for buildings. BSI, London, UK.

BSI (2005) BS EN 1990:2002 + A1:2005: Basis of structural design. BSI, London, UK.

BSI (2011) BS EN 15978:2011: Sustainability of construction works: assessment of environmental performance of buildings: calculation method. BSI, London, UK.

BSI (2012) PAS 111: Processing wood waste. BSI, London, UK

BSI (2017) BS 8001:2017: Framework for implementing the principles of the circular economy in organizations - guide. BSI, London, UK.

C2C (2017) Cradle to Cradle Certified ${ }^{C M}$ Banned List of Chemicals. McDonough Braungart Design Chemistry, Charlottesville, VA, USA. See http://s3.amazonaws.com/c2c-website/resources/certification/ standard/C2CCertified_Banned_Lists_V3_121113.pdf (accessed 05/11/ 2017).

CBI (Centre for the Promotion of Imports) (2017) Exporting CLT to Western Europe. CBI, Hague, the Netherlands. See https://www.cbi.eu/ market-information/timber-products/cross-laminated-timber/europe/ (accessed 17/03/2018).

CCC (Climate Change Committee) (2017) Meeting Carbon Budgets: Closing the Policy Gap. CCC, London, UK. See https://www.theccc. org.uk/wp-content/uploads/2017/06/2017-Report-to-Parliament-MeetingCarbon-Budgets-Closing-the-policy-gap.pdf (accessed 17/03/2018).

Cheshire D (2016) Building Revolutions: Applying the Circular Economy to the Built Environment. Riba Publishing, London, UK.

CIB (International Council for Research and Innovation in Building and Construction) (2014) Barriers for Deconstruction and Reuse/Recycling of Construction Materials. CIB, Delft, the Netherlands, Publication 397.

Cradle to Cradle Products Innovation Institute (2016) Products Standards, v3.1m. Cradle to Cradle Products Innovation Institute, Oakland, CA, USA. See http://s3.amazonaws.com/c2c-website/ resources/certification/standard/C2CCertified ProductStandard V3. 1_160107_final.pdf (accessed 05/11/2017).

Dangel U (2017) Turning Point in Timber Construction: a New Economy. Birkhäuser, Basel, Switzerland.

Ebner G (2017) CLT Production Is Expected to Double until 2020. See https://www.timber-online.net/holzprodukte/2017/06/brettsperrholzproduktion-in-europa-20162020.html (accessed 15/02/2018).

EEA (European Environment Agency) (2017) Annual European Union Greenhouse Gas Inventory 1990-2015 and Inventory Report. EEA, Copenhagen, Denmark. See https://www.eea.europa.eu/publications/ european-union-greenhouse-gas-inventory-2017/\#parent-fieldname-title (accessed 05/11/2017).

EMF (Ellen MacArthur Foundation) (2017a) Circular Economy: a Wealth of Flows, 2nd edn. EMF, Cowes, UK.

EMF (2017b) Cities in the Circular Economy: an Initial Exploration. EMF, Cowes, UK.

Eurostat (2017a) Wood Products - Production and Trade. Eurostat, Luxembourg. See http://ec.europa.eu/eurostat/statistics-explained/index. php/Wood_products_-_production_and_trade (accessed 15/02/2017).
Eurostat (2017b) Forestry and Climate Change. Eurostat, Luxembourg. See http://ec.europa.eu/eurostat/statistics-explained/index.php/ Forestry and climate change (accessed 05/11/2017).

Farmer M (2016) Modernise or Die, Time to Decide the Industry's Future: the Farmer Review of the UK Construction Labour Model. Construction Leadership Council, London, UK.

Forestry Commission (2018) Forestry Statistics and Forestry Fact and Figures. Forestry Commission, Bristol, UK. See https://www.forestry. gov.uk/forestry/infd-7aqdgc (accessed 17/03/2017).

Hairstans R (2017) Mass Timber: an Introduction to Solid Laminate Timber Systems. Arcamedia, Edinburgh, Scotland.

Hasslacher (2018) X-fix C. Hasslacher, Sachsenburg, Austria. See https:// www.hasslacher.com/en/x-fix-c (accessed 25/04/2018).

Hebel D and Heisel F (2017) Cultivated Building Materials, Industrialised Natural Resource for Architecture and Construction. Birkhäuser, Basel, Switzerland.

Hebel D, Wisniewska M and Heisel F (2014) Building from Waste, Recovered Materials in Architecture and Construction. Birkhäuser, Basel, Switzerland.

Hill J (2015) The circular economy: from waste to resource stewardship, part 1. Proceedings of the Institution of Civil Engineers - Waste and Resource Management 168(1): 3-13, https://doi.org/10.1680/warm.14. 00003.

HMG (Her Majesty's Government) (2013) Construction 2025, Industrial Strategy: Government and Industry Partnership. The Stationery Office, London, UK. See https://www.gov.uk/government/uploads/ system/uploads/attachment_data/file/210099/bis-13-955-construction2025-industrial-strategy.pdf (accessed 12/01/2018).

HS2 (2016) Press Release: 7 Million Trees to Be Planted as Part of HS2 First Phase. HS2, London, UK. See https://www.gov.uk/government/ news/seven-million-trees-to-be-planted-as-part-of-hs2-first-phase (accessed 17/03/2018).

lacovidou E, Purnell P and Lim MK (2018) The use of smart technologies in enabling construction components reuse: a viable method or a problem creating solution? Journal of Environmental Management 216: 214-223.

IStructE (Institution of Structural Engineers) (2014) Building for a Sustainable Future: an Engineer's Guide. IStructE, London, UK.

John S and Buchannan A (2016) End of Life Scenarios for Structural Timber Buildings in Australia and New Zealand. University of Canterbury, Christchurch, New Zealand, Report STIC-2013-01.

Kaufmann $\mathrm{H}$ and Nerdinger W (2012) Building with Timber, Paths into the Future. Prestel, New York, NY, USA.

Lignatec (2015) Climate-Friendly and Energy-Efficient Construction with Wood: Basic Information and Implementation. Lignum, Zurich, Switzerland.

Marsh B (2007) One Coleman Street: a Case Study in the Use of Secondary Materials in Construction: Institute of Concrete Technology Yearbook 2006-2007. Institute of Concrete Technology, Surrey, UK.

McDonough W and Braungart M (2003) Cradle to Cradle: Remaking the Way We Make Things. Rodale Press, Emmaus, PA, USA.

Meadows D (2008) Thinking in Systems: a Primer. Chelsea Green Publishing, Hartford, VT, USA

NHBC (National House-Building Council) (2016) Modern Methods of Construction: Views from the Industry. NHBC, Milton Keynes, UK, NF70.

PE International (2013) Cross Laminated Timber Dataset. See https:// woodforgood.com/lifecycle-database/structural-products/ (accessed 05/ 11/2017).

Pomponi F and Moncaster A (2017) A theoretical framework for circular economy research in the built environment. In Building Information Modelling, Building Performance, Design and Smart Construction (Dastbaz M, Gorse C and Moncaster A (eds)). Springer, Cham, Switzerland, pp. 31-44. 
Engineering Sustainability

Volume 172 Issue ES3
Mass timber in the circular economy: paradigm in practice?

Campbell
Ramage M, Burridge $\mathrm{H}$, Busse-Wicher $\mathrm{M}$ et al. (2017) The wood for the trees: the use of timber in construction. Renewable and Sustainable Energy Reviews 68: 333-359.

Raworth K (2017) Doughnut Economics, Seven Ways to Think Like a 21stcentury Economist. Random House Business Books, London, UK.

RICS (Royal Institution of Chartered Surveyors) (2018) Whole Life Carbon Assessment for the Built Environment, 1st edn. RICS London, UK. See http://www.rics.org/uk/upholding-professional-standards/sectorstandards/building-surveying/whole-life-carbon-assessment-for-thebuilt-environment/ (accessed 03/04/2019).

RSA (Royal Society for the encouragement of Arts, Manufactures and Commerce) (2016) Designing for a Circular Economy: Lessons from the Great Recovery 2012-2016. RSA, London, UK.

Schofield C (2016b) The Circular Building: The Most Advanced Reusable Building Yet. Arup, London, UK. See https://www.arup.com/news-andevents/news/the-circular-building-the-most-advanced-reusablebuilding-yet (accessed 17/03/2018).

SCI (2017) https://www.steelconstruction.info/File:Market_share.png (accessed 05/11/2017).

Stahel WR (1982) Product-Life Factor. Product-Life Institute, Geneva, Switzerland. See http://www.product-life.org/en/major-publications/ the-product-life-factor (accessed 17/10/2017).
Strykowski W (2013) Wood - a substitute or a raw material substituted for. Annals of Warsaw University Life Sciences - SGGW, Forestry and Wood Technology 84: 194-200.

TRADA (2012) Introduction to Wood-based Panel Products. TRADA Technology, High Wycombe, UK, Wood Information Sheet WS 2/3-23.

TRADA (2017) National Structural Timber Specification for Building Construction, Version 2.0: Exova BM TRADA. TRADA Technology, High Wycombe, UK.

UKGBC (UK Green Building Council) (2017) Embodied Carbon: Developing a Client Brief. UKGBC, London, UK. See https://www. ukgbc.org/sites/default/files/UK-GBC\%20EC\%20Developing\% 20Client\%20Brief.pdf (accessed 05/11/2017).

UNECE (UN Economic Commission for Europe) (2015) State of Europe's Forests. UNECE, Geneva, Switzerland. See http://www.foresteurope. org/docs/fullsoef2015.pdf (accessed 05/11/2018).

UN Sustainable Development Goals (2017) https://sustainabledevelopment. un.org/sdgs (accessed 17/10/2017).

Waugh A, Weis K and Wells M (2009) A Process Revealed. Murray \& Sorrell Fuel Design and Publishing, London, UK.

Weetman C (2017) A Circular Economy Handbook for Business and Supply Chains. Kogan Press, London, UK.

\section{How can you contribute?}

To discuss this paper, please email up to 500 words to the editor at journals@ice.org.uk. Your contribution will be forwarded to the author(s) for a reply and, if considered appropriate by the editorial board, it will be published as discussion in a future issue of the journal.

Proceedings journals rely entirely on contributions from the civil engineering profession (and allied disciplines). Information about how to submit your paper online is available at www.icevirtuallibrary.com/page/authors, where you will also find detailed author guidelines. 